九州大学学術情報リポジトリ

Kyushu University Institutional Repository

\title{
Geographical Distribution of Biovars of Ralstonia solanacearum in Brazil
}

Melo, Maria Salete de

Laboratory of Plant Pathology, Faculty of Agriculture, Kyushu University

Furuya, Naruto

Laboratory of Plant Pathology, Faculty of Agriculture, Kyushu University

I i yama, Kazuhiro

Laboratory of Plant Pathology, Faculty of Agriculture, Kyushu University

Khan, Abu Ashraf

Laboratory of Plant Pathology, Faculty of Agriculture, Kyushu University

他

https://doi.org/10.5109/24300

出版情報: 九州大学大学院農学研究院紀要. 44 (1/2), pp.9-15，1999-11. Kyushu University バージョン：

権利関係 : 


\title{
Geographical Distribution of Biovars of Ralstonia solanacearum in Brazil
}

\author{
Maria Salete de Melo, Naruto Furuya, Kazuhiro Liyama*, \\ Abu Ashraf Khan and Nobuaki Matsuyama
}

Laboratory of Plant Pathology, Faculty of Agriculture, Kyushu University, Fukuoka 812-8581, Japan

(Received June 21, 1999 and accepted August 24, 1999)

\begin{abstract}
Fifty-seven bacterial wilt pathogens were isolated from infected tomato, eggplant, potato, cucumber, pepper, banana, Solanum gilo and eucalyptus plants collected at different regions in Brazil. They were identified as Ralstonia solanaceamm by the routine identification tests and the TLC method. The isolates were divided into seven groups on the basis of pathogenicity tests to tomato, eggplant, potato and tobacco. Moreover, hased on the results of cultural, physiological and biochemical tests, twenty-four isolates were grouped as biovar 1 , seventeen as biovar 2 and sixtecn as biovar 3 . Biovar 1 isolates are common and widely distributed in Brazil. Biovar 2 isolates are predominant on potato and prevail in the central west, south-east and south areas. Biovar 3 isolates exist mainly in the northern and north-eastern parts of Brazil.
\end{abstract}

\section{INTRODUCTION}

Raistonia (syn. Burkholderia, Pseudomonas) solanacearum (E. F. Smith) Yabuuchi et al, the causal agent of bacterial wilt, is an important plant pathogenic bacterium in tropical, subtropical and warm temperate regions, causing great losses in production of many crops in worldwide including Brazil (Kelman, 1953, Hayward, 1991). Its isolates from different countries have so far been grouped into five races and five biovars (Hayward, 1964, French and Sequeira, 1970, He et al., 1983).

The importance of bacterial wilt in Brazilian agriculture is confirmed by the number of papers published on this subject (Mariano et al., 1998). The high destructive capacity of $R$. solanaceamum coupled with its large host range has meant that this pathogen is still associated with heavy losses. Thus, there is a need for more in depth studies on host range, biovar distribution, survival, epidemiology and control of $R$. solanacearum.

The present study was undertaken to characterize the bacterial wilt pathogen and to clarify its biovar distribution in Brazil.

\section{MATERIALS AND METHODS}

\section{Isolation and preservation of bacterial wilt pathogen}

Pepper, potato, tomato, eggplant, cucumber, eucalyptus, banana and Solanum gilo which showed symptoms of bacterial wilt were collected from different locations in Brazil (Table 1). Bacteria were isolated from diseased stem tissues by cutting and soaking in

* Present address: Kawanabe Agricultural Improvement and Advisory Center, Kawanabe-gun, Kagoshima, 897-0221, Japan 
Table 1. Brazilian isolates used in this experiment.

\begin{tabular}{|c|c|c|c|c|c|}
\hline Bacterial isolate & Host & Place & Bacterial isolate & Host & Place \\
\hline $\begin{array}{l}13,72,92,128,578 \\
613,799,933\end{array}$ & potato & Brasilia & $19,628,630$ & tomato & Para \\
\hline $61,113,131$ & potato & Parana & $31,33,35$ & tomato & Amapa \\
\hline 66 & potato & Minas Gerais & 855,1033 & tomato & Brasilia \\
\hline 67 & potato & Bahia & $62,76,985$ & tomato & Pernambuco \\
\hline $98,106,964$ & potato & Santa Catarina & 140,535 & tomato & Amazonas \\
\hline 982,1005 & potato & Rio de Janeiro & $\begin{array}{l}49,1102,1103 \\
1104\end{array}$ & tomato & Maranhao \\
\hline 7 & pepper & Amazonas & 51 & eggplant & Para \\
\hline 127 & pepper & Brasilia & 56 & eggplant & Pernambuco \\
\hline 162 & pepper & Maranhao & $71,79,87$ & eggplant & Brasilia \\
\hline 582 & pepper & Ceara & 534 & eggplant & Maranhao \\
\hline 20,629 & pepper & Para & $\begin{array}{l}574,575,576,577, \\
579,603\end{array}$ & eucalyptus & Para \\
\hline 129 & cucumber & Brasilia & 47 & Solanum gilo & Amazonas \\
\hline 656 & cucumber & Amazonas & 73 & banana & Sergipe \\
\hline
\end{tabular}

sterile distilled water. The resulting suspension was streaked onto tetrazolium chloride (TTC) medium, which is semi-selective for Ralstonia solanacearum. The plates were incubated at $30^{\circ} \mathrm{C}$ for 3 days. Bacterial colonies displaying characteristics of $R$. solanacearum were selected and purified by re-streaking on TTC medium. Fifty-seven isolates listed in Table 1 were selected for further tests. A type strain (ATCC11696) and Japanese strain (C319) of $R$. solanacearum were used as positive reference cultures for all determinative tests. The individual virulent colonies were selected based on cultural characteristics and preserved in sterilized distilled water in screw capped test tubes at room temperature.

\section{Pathogenicity test}

Fifty-seven isolates of the suspect bacteria were tested for pathogericity on tobacco (Nicotiana tabacum L. cv. White Burley), tomato (Lycopersicon esculentum mill. cv. Sekai ichi), eggplant (Solanum melongena cv. Chikuyou) and potato (Solanum tuberosum L. cv. Dejima).

Inocula were prepared as followed; each bacterial stock suspension in sterile distilled water was spread on TTC medium, and the plate was incubated at $30^{\circ} \mathrm{C}$ for $48 \mathrm{hr}$ for selecting virulent colonies. Typical virulent colonies were inoculated by the stem-puncture method (Winstead and Kelman, 1952). Sterile distilled water was used as a control. The inoculated plants were incubated at $30^{\circ} \mathrm{C}$ for $24 \mathrm{hr}$ in a moist chamber (RH $100 \%$ ), then transferred to a greenhouse bench at $25-30^{\circ} \mathrm{C}$. The inoculated plants were observed daily to record wilt symptom for 30 days.

\section{Identification and characterization of isolates}

The following tests were carried out according to the method described in the references to characterize the pathogenic fifty-seven isolates: Gram reaction (Gredersen, 
1978), levan production (Hildebrand, 1988), poly- $\beta$-hydroxybutyrate (PHB) accumulation (Hildebrand, 1988), oxidase reaction (Kovacs, 1956), catalase production (Digat, 1971), gelatin liquefaction (Frazier, 1926), indole production (Hayward, 1964), arginine dihydrolase (Thomley, 1960), starch hydrolysis (Sands et al., 1980), lecithinase (egg yolk) (Mc Clung and Toabe, 1947), pigment production (Kelman, 1954). Nutritional studies were also performed. All carbon sources were filter-sterilized and added to the Ayer's basal medium (Pelczar, 1957) to give a final concentration of $0.5 \%(\mathrm{w} / \mathrm{v})$. A suspension of bacterial cells grown on TTC agar medium was inoculated into broth of each test medium, incubated at $30^{\circ} \mathrm{C}$, and the characteristics were evaluated periodically for 21 days.

\section{Simple TLC}

The simple TLC (Khan and Matsuyama, 1998) was conducted for the isolates including the type strain ATCC 11696 and C319 of $R$. solanacearum. Each isolate was grown on slant of King's B medium (Eiken Chem. Co., Tokyo) at $30^{\circ} \mathrm{C}$ for 3 days. One loopful of bacterial cells was suspended in $0.2 \mathrm{ml}$ of chloroform-methanol $(2: 1, \mathrm{v} / \mathrm{v})$ in a small glass vial and kept at least for $15 \mathrm{~min}$ at room temperature for lipid extraction. Ten $\mu \mathrm{l}$ of lipid extract was spotted on the origin of silica gel 'l'LC plate and completely dried by a drier. The plate was developed with chloroform-methanol- $0.2 \%$ calcium chloride solution $(55: 35: 8, \mathrm{v} / \mathrm{v} / \mathrm{v})$ at $25^{\circ} \mathrm{C}$ for $1 \mathrm{hr}$. After development, aminolipid spots were detected by spraying ninhydrin followed by heating at $100^{\circ} \mathrm{C}$ in an oven for $10 \mathrm{~min}$. The chromatograms were recorded by photocopy, photograph and/or computer (Adobe Photoshop 3.0J).

\section{Biovar identification}

To classify the isolates into biovars, carbohydrate oxidation test was conducted following standard procedures (Hayward, 1964, 1976, He et al., 1983, Swanepoel and Young, 1988). In this test, three disaccharides (cellulose, lactose and maltose) and three hexose alcohols (dulcitol, mannitol and D-sorbitol) were used.

\section{RESULTS AND DISCUSSION}

\section{Characterization of isolates}

All isolates tested in the present study produced highly fluidal, creamy-white colonies with light pink or pinkish red center on TTC medium after $48 \mathrm{hr}$. The characteristics of the isolates revealed that all cultures were virulent isolates of $R$. solanacearum (Kelman, 1954; Hayward, 1964). They showed $R$. solanacearum type of chromatographic profile under direct colony TLC and simple TLC tests as described by Matsuyama et al. (1993a, 1993b) and Khan and Matsuyama (1998), respectively. All were palkogeruc to at least one kind of plant tested and produced characteristic symptoms of bacterial wilt after inoculation. In particular, all isolates were pathogenic to tomato plant.

All isolates were gram-negative, and cells accumulated poly- $\beta$-hydroxybutyrate (PHB) as a carbon reserve material. They gave a negative reaction for arginine dihydrolase, indole production, starch hydrolysis, gelatin liquefaction, levan production and lecithinase. In the test for utilization of carbon source, all isolates gave positive 
Table 2. Comparison of physiological and biochemical characteristics of Brazilian isolates with Ralstonia solanacearum.

\begin{tabular}{|c|c|c|c|}
\hline Characteristic & $\begin{array}{l}\text { Brazilian isolate } \\
(57)^{\text {it }}\end{array}$ & $\begin{array}{l}\text { R. solanaceamum } \\
\text { ATCC11696 }\end{array}$ & R. solanacearum ${ }^{\text {b }}$ \\
\hline Pigment producution & $d$ & + & $d$ \\
\hline Indole production & - & - & - \\
\hline Levan formation from sucrose & - & - & - \\
\hline Lecithinase & - & - & - \\
\hline Catalase & + & + & + \\
\hline Arginine dihydrolase & - & - & - \\
\hline Oxidase & + & + & + \\
\hline Hydrolysis of & & & \\
\hline Starch & - & - & - \\
\hline Gelatin & - & - & - \\
\hline Poly- $\beta$-hydroxybutyrate accumulation & + & + & + \\
\hline Utilization of & & & \\
\hline glucose & + & + & + \\
\hline$\alpha$-ketoglutarate & + & + & + \\
\hline$m$-hydroxybenzoate & - & - & - \\
\hline$\alpha$-amylamine & - & - & - \\
\hline levulose & + & + & + \\
\hline testosterone & - & - & - \\
\hline L-histidine & + & + & + \\
\hline adonitol & - & - & - \\
\hline erythritol & - & - & - \\
\hline saccharate & + & + & + \\
\hline 2,3 butylene glycol & - & - & - \\
\hline geraniol & - & - & - \\
\hline meso-inositol & + & $\perp$ & $\mathrm{d}$ \\
\hline$\beta$-alanine & d & + & d \\
\hline D-ribose & $\mathrm{d}$ & + & $\mathrm{d}$ \\
\hline levulinate & . & - & d \\
\hline $\mathrm{L}(+)$ tartrate & $\mathrm{d}$ & + & d \\
\hline meso-tartrate & $\mathrm{d}$ & + & d \\
\hline azzelate & d & - & d \\
\hline L-serine & + & + & $\mathrm{d}$ \\
\hline sarcosine & $\mathrm{d}$ & + & d \\
\hline glycolate & d & - & d \\
\hline p-hydroxybenzoate & - & - & $\mathrm{d}$ \\
\hline trehalose & d & + & + \\
\hline$L$-valine & d & - & - \\
\hline D-xylose & $\mathrm{d}$ & - & - \\
\hline L-rhamnose & d & - & - \\
\hline citraconate & d & - & - \\
\hline mesaconate & $\mathrm{d}$ & - & - \\
\hline malonate & d & - & - \\
\hline betaine & $\mathrm{d}$ & - & - \\
\hline $\mathrm{L}$-arabinose & d & - & - \\
\hline
\end{tabular}

Symbols: $+=$ positive, $-=$ negative, $\mathrm{d}=\mathbf{1 1}-89 \%$ of strains are positive.

a) Fifty-seven isolates were tested.

b) Data from Bergy's Mannual of Systematic Bacteriology (Palleroni, 1984). 
reactions for glucose, $\alpha$-ketoglutarate, levulose, L-histidine, saccharate, meso-inositol and $\mathrm{L}$-serine. They showed negative reactions in the test for utilization of $\mathrm{m}$-hydroxybenzonate, $\alpha$-amylamine, testosterone, adonitol, erythritol, 2,3-butylene glycol, geraniol and $p$-hydroxybenzoate. The above results of physiological and biochemical tests are the cvidence of $R$. solanacearum (Table 2).

On the basis of pathogenicity tests, Brazilian isolates of $R$. solanacearum were divided into seven groups (Table 4). Considerable variations in Brazilian isolates were also observed in regard to utilization of trehalose, D-xylose, L-arabinose, L-rhamnose, L-valine, citraconate, mesaconate, malonate and betaine (Table 2).

\section{Biovar identification and their distribution}

Marked differences were observed in the ability of the isolates of $R$. solanacearum to

Table 3. Confirmatory test for determination of biovar of Ralstonia solanacearum isolates from Brazil.

\begin{tabular}{|c|c|c|c|c|c|c|c|}
\hline \multirow{3}{*}{ Biovar } & \multicolumn{6}{|c|}{ Results for carbohydratc oxidation test } & \multirow{3}{*}{ Isolate } \\
\hline & \multicolumn{3}{|c|}{ Disaccharides } & \multicolumn{3}{|c|}{ Hexose alcohols } & \\
\hline & ccllobiose & lactose & maltose & dulcitol & mannitol & sorbitol & \\
\hline 1 & - & - & - & - & - & - & $\begin{array}{l}13,19,31,72,73,76,127,128,129,140 \\
574,575,576,577,578,579,603,613 \\
629,656,982,985,1005,1033\end{array}$ \\
\hline 2 & + & + & + & - & - & - & $\begin{array}{l}7,61,66,67,71,79,87,92,98,106,113 \\
131,162,799,855,933,964\end{array}$ \\
\hline 3 & + & + & + & + & + & + & $\begin{array}{l}20,332,35,47,49,51,56,62,534,635 \\
582,628,630,1102,1103,1104\end{array}$ \\
\hline 4 & - & - & - & + & + & + & not isolated \\
\hline 5 & + & + & + & - & - & - & not isolated \\
\hline
\end{tabular}

Table 4. Pathogenicity of Brazilian isolates of Ralstonia solanaceamim to tomato, eggplant, potato and tobacco plants.

\begin{tabular}{|c|c|c|c|c|c|}
\hline \multirow{2}{*}{$\begin{array}{l}\text { Tentative } \\
\text { grouping }\end{array}$} & \multicolumn{4}{|c|}{ Pathogenicity } & \multirow[b]{2}{*}{ Brazilian isolate } \\
\hline & tomato & eggplant & potato & tobacco & \\
\hline I & + & + & + & + & $19,98,127,574,578,613,630$ \\
\hline II & + & + & + & - & $\begin{array}{l}7,13,20,33,51,56,61,62,66 \\
79,131,534,535,579,582 \\
603,656,799,855,933,964, \\
1033,1102\end{array}$ \\
\hline III & + & + & - & + & 628 \\
\hline IV & + & + & - & - & 140,985 \\
\hline $\mathrm{V}$ & + & - & + & - & $\begin{array}{l}31,35,67,72,76,87,92,106 \\
113,128,162,575,576,577 \\
982,1005,1103\end{array}$ \\
\hline $\mathrm{VI}$ & + & - & - & + & 629,1104 \\
\hline VII & + & - & - & - & $47,49,71,73,129$ \\
\hline
\end{tabular}


oxidize three disaccharides and three hexose alcohols. Twenty-four isolates did not oxidize any disaccharides and hexose alcohols. They were classified as biovar 1. Seventeen isolates oxidized disaccharides but not any hexose alcohols, and classified as biovar 2 . Sixteen isolates oxidized both groups of carbohydrates, and were classified as biovar 3. Any isolates belonging to biovar 4 or 5 were not isolated in Brazil (Table 3).

As can be seen in Fig. 1, the frequency of presence in the collection of biovars isolated in Brazil was plotted on a map with information about the host plants. Biovar 1 isolates are common and widely distributed in Brazil. Biovar 2 isolates are predominant on potato and prevail in the central west, south-east and south areas. Biovar 3 isolates exist mainly in the northern and north-eastern parts of Brazil. Thus, the geographical distribution of each biovar varied in Brazil.
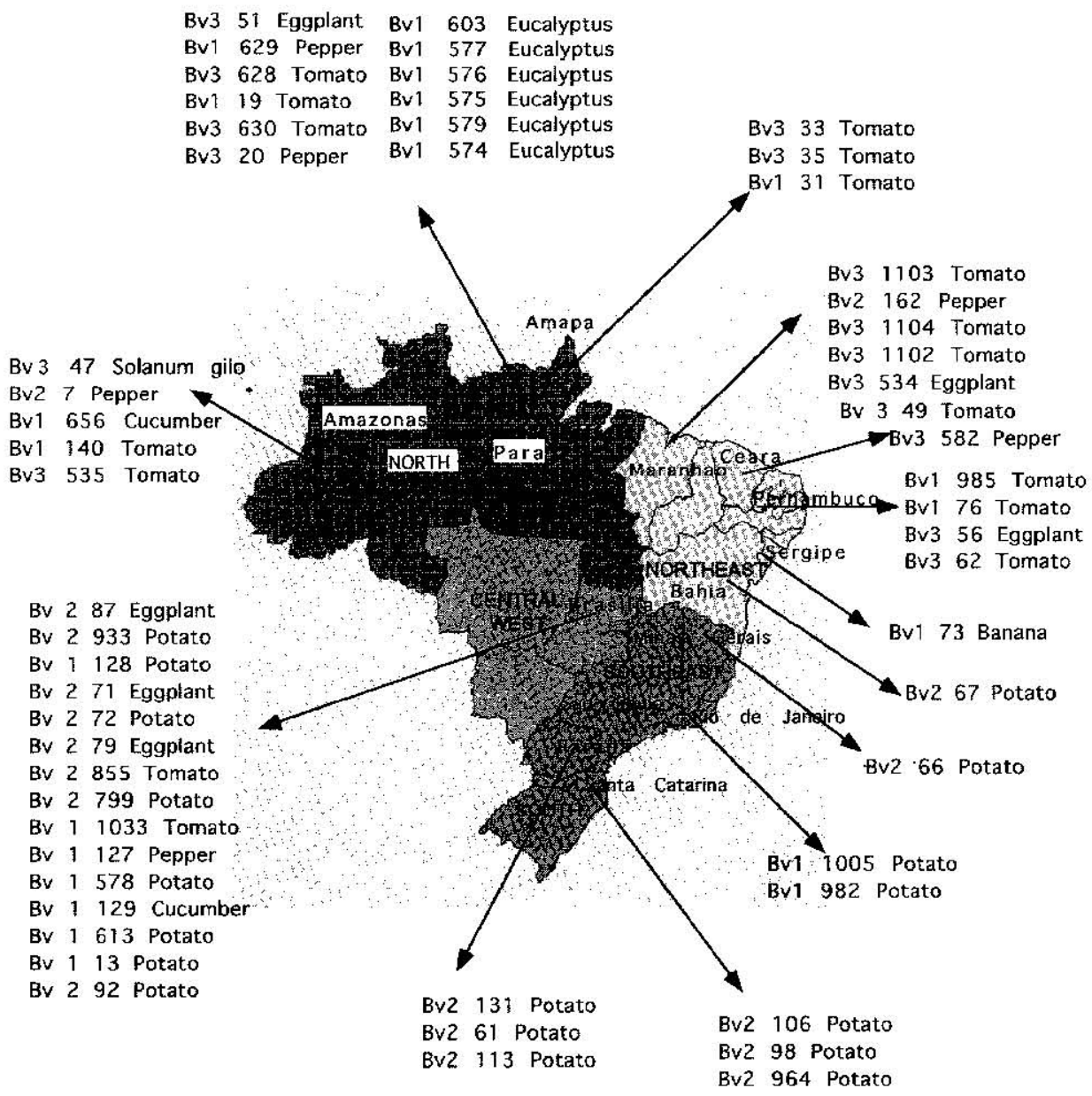

Fig. 1. Geographical distribution of biovars 1,2 and 3 of Ralstonia solanacearum in Brazil. 


\section{REFERENCES}

Digal, B. 1971 The significance of catalase activity in Pseudomonas solanacearum. PP. $71-75 \mathrm{ln}$ Proc. Int. Conf. Plant pathog. Bact. 3 H. H. M. Geesteranus (eds)

Frazier, W. C. 1926 A method for the detcetion of changes in gelatin due to bacteria. J. Infect. Dis., 39: 302

French, E. R. and L. Sequeira 1970 Strains of Pseudomonas solanacearum from Central and South America: A comparative study. Phytoputhology, 60: 507-512

Gregersen, T. 1978 Rapid method for distinction of gram-negative from gram-positive bacteria. Eur. $J$. Appl. Microbiol. Biotechnol., 5: 123-127

Hildebrand, D. C., M. N. Schroth and D. C. Sands 1988 Psendomonas. Pages 60-81 In Laboratory (iuide for Identification of Plant Pathogenic Bacteria. $2^{m \cdot 1}$ Edition. Schaad. N. W. (eds.) APS Press

Hayward, A. C. 1964 Characteristics of Pseudomonas solanacearum. J. Appl. Buct., 27(2): 265-277

Hayward, A. C. 1976 Some lechniques of importance in the identification of Pseudomonas solanaceamum. PP. 137-142. In Proc. Int. Plant. Conf. Workshop Ecol. Control Bacterial Wilt caused by Pseudomonas solanacearum, L. Sequeira and Kelman (eds.), North Carolina State University. Raleigh. $166 \mathrm{pp}$.

Hayward, A. C, 1991 Biology and epidemic of bacterial wilt caused by Pseudomonas solonacearum. Ann. Rev. Phytopath., 29: $65-87$

Hc, Y., L. Sequeira and A. Kelman 1983 Characteristics of strains of Pseudomonas solanacearum from China. Plant Dis, 67: 1357-1361

Khan, A. A. and N. Matsuyama 1998 Rapid identificatiou of phytopathogenic bacteria by TI.C. J. Fac: Agr, Kyushu Univ., $\mathbf{4 2}(3,4)$ 281-287

Kelman, A. 1953 The bacterial wilt caused by Pseudomonas solaracearum. Tec. Bull. 99, North Carolina Agril. Exp. Sta. North Carolinla, L.S.A. 194 pp.

Kelman, A. 1954 The relationship of pathogenicity in Pseudomonas solanacearum to colony appearance on a tetrazolium medium. Phylopathology, 44: 693-695

Kovaes, N. 1956 Identification of Pseudomonas pyocynea by the oxidase reaction. Nature, 178: 173

Mariano, R. L. R., N. S. S. Silveira and S. J. Michereff 1998 Bacterial wilt in Brazil; Current Status and control methods. In Bacterial Wilt, Disease. Prior, Ph., C. Allen and J. Elphinstone (eils.). pp 386-393 INRA

Matsuyama, N., I. H. Mian, A. M. Akanda and N. Furuya 1993a Comparative studies on thin-layer chromatograms of lipids from various phytopathgenic bacteria. Ann. Phytopath. Soc. Jpn., 59: 528-534

Matsuyama, N. and N. Furuya 1993b Application of the dircet colony TLC for identification of phytopathogenic bacteria (II). Chromatographic profile of Eruinia and Pseudomonas spp.. J. Fac: Agr: Kyushu Univ., 38(1-2): 89-95

Mc Clung, L. S. and R. Toabe 1947 The egg yolk plate reaction for the presumptive diagnosis of Clostridium sporogenes and certain species of the gangrene and botulinum groups. J. Bacteriol., 53: $139-147$

Palleroni, N. J. 1984 Genus 1. Pseudomonas Migula 1894 In Bergey's Manual of Systematic: Bacteriology Volume 1: 141-199. Williams \& Wilkins, Baltimore

Pelczar, M. J. Jr. ed. 1957 Manual of Microbiological Methods. Megraw-Hill Book Company, Inc., New York

Swanepoel, A. E. and B. W. Young 1988 Characteristics of South African strains of Pseudomonas solanacearum. Plant Dis., 72(5): 403-405

Thoruley, M. J. 1960 The differentation of Psesudomonas from other gram-rnegative bacteria on the basis of arginine metabolism. J. Appl. Bacteriol, 23: 37-52

Winstead, N. N. and A. Kelman. 1952 Inoculation techniques for evaluating resistance to l'seudomonas solanacearum. Phytopathology, 42: 628-634 